уДК 791.43.03(450)"19"

ББК 85.374.3(4Ита)6-8Феллини Ф.

\title{
П.Р. ГАМЗАТОВА
}

\section{ЛИМИНАЛЬНОСТЬ КАК АРХЕТИП В ТВОРЧЕСТВЕ Ф. ФЕЛЛИНИ}

\begin{abstract}
Анализируются характерные структурные особенности фильмов Федерико Феллини: нелинейное повествование, бесцельность, хаотичность коллизий сюжета (кризисные состояния социума и человека), характер героев фильма (маргинальность, персонажи смеховой культуры и связанные с творчеством); специфика главного лирического героя и альтер эго самого Феллини (М. Мастроянни), воплощающего собой растерянное, бесформенное, бессмысленное лицо в мире «смысло-лиц». Автор статьи приходит к следующему выводу: лиминальность (или пороговое состояние - понятие, выработанное и проанализированное в этнологии) является одним из архетипов сознания, моделирующих художественные структуры и наиболее ярко проявившимся в творчестве Ф. Феллини.

Ключевые слова: Федерико Феллини, Виктор Тэрнер, лиминальность, маргинальность, обряды перехода, переходные и пограничные состояния, матрицы сознания, модель творчества, точка бифуркации, хаос, структура, архетип, кризисное состояние системы, формо-смыслы.
\end{abstract}

И зучение соотношения архетипических основ художественного творчества и личностного авторского решения, основанного на индивидуальном жизненном и духовном опыте, которое можно наблюдать в том или ином произведении искусства, имеет огромное значение. Фильмы Федерико Феллини поражают своей фантастичностью, странным хаосом потрясающих образов и одновременно математической точностью образного высказывания, за которым словно угадывается некий закон всечеловеческого существования. Так, С. Аверенцев писал

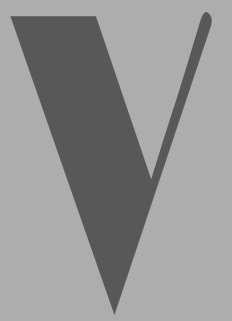

ИМЕНА. ПОРТРЕТЫ 
о том, что, согласно концепции К. Юнга, «воздействие искусства <...> состоит в способности художника точно реализовать архетипические схемы в своих произведениях» [1]. Именно раскрытию одного из этих архетипов в творчестве Феллини и посвящена данная статья.

Прежде всего стоит обратиться к так называемым «0брядам перехода» (rites de passage), рассматривая их не только как социальные механизмы жизни архаического общества, но и с точки зрения их духовного и художественного содержания. Анализируя «обряды перехода», известный английский этнограф Виктор Тернер, вслед за Арнольдом Ван Геннепом, обратил внимание на значительную роль, которую играют данные ритуалы в жизни архаического общества. Они сопровождают любую перемену социального статуса человека и состоят из трех фаз:

- отделение от определенной социальной структуры;

- лиминальное (или пороговое) состояние;

- восстановление в социуме [2, с. 168-169].

В. Тернер исследовал и дал развернутую характеристику такому понятию, как лиминальность и рассмотрел две системы общества, одну из которых назвал коммунитас, а другую - структура. Существует устойчивая диалектическая связь между этими состояниями, переживать их может как само общество, так и отдельный индивид. Структура - это своеобразная модель общества и модель человека в обществе, когда за ним закреплены определенные иерархические, социально-правовые, родовые и другие положения. В коммунитас, которая имеет важнейшее значение в ритуале и социальной жизни людей, человек как бы выходит из этих структур и приобретает некоторые новые качества. Этот закон жизни архаического общества, являющийся универсальным для ритуальных ситуаций и особенно инициационных обрядов, имеет, как показал В. Тернер, множество параллелей с историческими и современными социальными процессами.

В контексте заявленной темы особенно важно, что прохождение коммунитас играет огромную роль в духовной жизни человека. «Почти всюду, - писал В. Тернер, к ней относятся как к сакральному или "блаженному", вероятно, потому что она нарушает или отменяет нормы, управляющие структурными и институционализированными отношениями, и сопровождается переживаниями небывалой силы. Процессы "уравнивания" и "обнажения" часто приводят своих субъектов в состояние полного аффекта. Все природные инстинкты человека, безусловно, высвобождаются с помощью этих процессов, однако теперь я склонен думать, что коммунитас - не просто продукт биологически унаследованных стремлений, вырвавшихся из-под культурных запретов. Скорее, это продукт специфически человеческих качеств, которые включают рациональность, волю, память и которые развиваются с опытом жизни в обществе <...> Дело в том, что между людьми существует родовая связь и обусловленное ею чувство “принадлежности к человечеству", которые не являются эпифеноменами какого-либо стадного инстинкта, а представляют собой продукт “людей в их целокупности, во всей их полноте". Лиминальность, маргинальность и низшее положение в структуре - условия, в которых часто рождаются мифы, символы, ритуалы, философские системы и произведения искусства <...> Пророки и художники имеют склонность к лиминальности и маргинальности, это пограничные люди, которые со страстной искренностью стремятся избавиться от клише, связанных со статусом и исполнением соответствующей роли...» [2, с. 198].

Здесь необходимо предварить дальнейший разговор о творчестве Федерико Феллини напоминанием об огромном значение маргинальных персонажей и пограничных людей в его произведениях. Так, Георгий Богемский цитирует одного из продюсеров, Гоффредо Ломбардо, который говорил режиссеру: «Это опасный фильм <...> (о фильме «Ночи Кабирии». - П.Г.). Одну картину ты поставил про бездельников («Маменькины сынки». - П.Г.), другую про грязных бродяг («Дорога», «0гни варьете». - П.Г.), третью про мошенников («Мошенничество». - П.Г.). Затем хотел снять фильм про сумасшедших (как пишет Г. Богемский: имеется в виду замысел Феллини экранизировать роман Марио Тобино «Свободные женщины из Мольяно» - из жизни врачей-психиатров. - П.Г.). Теперь фильм о проститутках!» [3, с. 32].

Маргинальные люди и лиминальные существа близки друг другу, но в то же время лиминальность - это и нечто совершенно другое. Это просто один, но революционный шаг за границу реального мира. В. Тернер выделяет ряд свойств, характеризующих положение лиминальных существ в коммунитас. Они - «ни здесь ни там, ни то ни се». Данное состояние уподобляется - смерти [2, с. 173], анонимности, бесполости [2, с. 176], приниженности, отсутствию статуса. Оно характеризуется постоянной связью с мистическими силами, глупостью, сакральностью [2, с. 179], экзистенциальными качествами, аффективностью переживания [2, с. 198]. В коммунитас происходит противопоставление общечеловеческих ценностей структурной власти и иерархии. В чередовании структуры и коммунитас, как в жизни архаического общества, так и в судьбе каждого отдельного человека, В. Тернер видел один из основных законов развития общества и человека в нем. Причем исследователь не только раскрыл логику этого движения, но дал и духовно-нравственную оценку самого лиминального состояния. Он утверждал его духовную значимость. Этот вывод представляется весьма интересным, так как лиминальность, несомненно, несет в себе черты хаоса и зачастую оценивается знаком минус. В точке зрения В. Тернера присутствует идея о неразрывности связи «коммунитас-структура».

Открытие этих законов позволило В. Тернеру поновому подойти ко многим проблемам культуры и социальных духовных движений, в частности «исследованиям схизматических движений, явлений бунта и протеста, феноменов паломничества» [4], к движению хиппи с их противостоянием структурным, политическим формам общества и нормативным формам культуры. Характерно, 
что В. Тернер обращается к творчеству Боба Дилана как выразителю духа коммунитас [2, с. 230]. В дальнейшем, изучая сам ритуальный процесс, В. Тернер вышел к «феноменам игры, драматическому представлению и, среди прочего, к современным театральным экспериментам (хеппенинг, перформанс и др.)» [4]. Таким образом, он провел несомненные параллели между антропологическими законами и художественными и духовными структурами, перешел к анализу сферы проявления коммунитас не только в культуре вообще, но и конкретно в искусстве, в театре. Ведь изменяется не только социальный статус, но и ценностные нормы, самосознание и, видимо, эмоциональное состояние. При этом важным оказывается не просто получение той или иной, пусть и художественной информации, но сам процесс переживания, движения. Согласно Л.С. Выгодскому, именно искусство перестраивает определенным образом наши эмоции и чувства, также как наука перестраивает наши мысли, а техника - физические возможности» [5, с. 297].

Одной из сфер проявления коммунитас В. Тернер считал «постоянно и временно сакральные свойства низкого статуса или положения», «силу слабого». «Члены презираемых и бесправных этнических групп либо культурных групп, - писал исследователь, - играют главнейшую роль в мифах и сказках как представители и выразители общечеловеческих ценностей» [2, с. 183].

Концепции коммунитас, лиминальности и структуры имеют явные корреляции с идеей энтропии и с теорией точки бифуркации И.Р. Пригожина. Когда наблюдается «критическое состояние системы, при котором система становится неустойчивой относительно флуктуаций и возникает неопределенность: станет ли состояние системы хаотическим или она перейдет на новый, более дифференцированный и высокий уровень упорядоченности» ${ }^{1}$.

Действительно, может ли лиминальность быть архетипом, своеобразной матрицей художественного творчества?

Как известно, архетипы - это элементы психических структур. Они связаны с мифологическими образами-продуктами сознания. «Юнг считал, - пишет С. Аверенцев, что архетипы имеют не содержательную, но формальную характеристику. Содержательную характеристику первообраз получает, когда проникает в сознание и наполняется материалом сознательного опыта» [1]. Архетипы - это не сам образ, а лишь схема образов, психологические предпосылки, возможность. К. Юнг сравнивал архетип с осями роста кристаллов [1], то есть как бы с программой роста кристаллов.

По всей вероятности, архетип - это система мироощущения. Он может медленно, но верно как бы разворачиваться, и его можно ощутить уже на раннем этапе творчества художника. Есть авторы, которые всю свою жизнь прорываются к своему мифу, жадно выхватывая у жизни

\footnotetext{
${ }^{1}$ Термин из теории самоорганизации. Точка бифуркации [Электронный ресурс]. - Режим доступа: http://ru.wikipedia.org/wiki
}

что-то из моря реальности, то, в чем они узнают родное $и$ близкое им. Покуда вдруг полный сюжет и некое - может законченное, а может и нет - произведение точно и ясно, логично и выстроенно не заявит о главном или не реализует его. Анализируя творчество А.Г. Тышлера, Д.В. Сарабьянов дал одну очень точную характеристику мифологическому и архетипическому. 0н написал, что о Тышлере можно сказать: он Тышлером родился, Тышлером жил и Тышлером умер [6]. Действительно, художник мифологический чувствуется сразу, хотя может не быть никакого конкретного мифа.

В собственном дискурсе Феллини не раз употреблял слово архетип в отношении конкретных лиц, образов. В своих воспоминаниях «Полная путаница» Камилла Чедерна писала о съемке фильма «81/2»: «С каждым днем он становился все озабоченнее и мрачнее, говоря, что двадцать или тридцать персонажей его фильма должны быть выбраны абсолютно точно. “Я ведь не имею возможности представить их зрителям, дать какие-то предварительные пояснения на их счет - лица у них должны быть такие, чтобы, как только они появятся на экране, мгновенно стать узнаваемыми масками. Все они - проекция главного персонажа, а следовательно, определенные, неизменные архетипы. Ну как мне тебе это объяснить. Словом, мне никак нельзя ошибиться"» [7, с. 195].

Действительно, увидеть - встретить человека во всей его живой, пластической, звуковой, духовной многогранности - это такое же визуальное событие, как увидеть, к примеру, Эйфелеву башню, Парфенон, собор в Шартре. Увидев собор или Парфенон, человек узнает чтото об истории, о духовном этапе, пережитом тем или иным социумом, но увидев определенное лицо-образ, человек узнает о себе подобном, о душе, чувствах, о генетической истории живого, о тех вселенских законах духовного и материального, к которым он причастен. Причины, почему запоминается то или иное лицо или произведение искусства, скрыта в подсознании ${ }^{2}$.

\footnotetext{
${ }^{2}$ Можно привести описание самого Феллини собственного процесса работы с актерами, его волнения, которое рождалось в душе мастера при встрече с «любым живым индивидуумом»: «Как правило, работая над сценарием, я уже ориентируюсь на определенного актера - исполни теля главной роли. Однако бывают случаи, когда мне приходится заново подбирать не только исполнителей второстепенных ролей, но и главных героев фильма. Тогда я переживаю мучительные минуты. Потому что я во всех них влюблен. Например, я себе заранее представил, что данный персонаж должен быть лысым, с волосатыми руками, низкорослый и картавящий. Таким я его вижу перед собой. Начинаются поиски актера, который должен отвечать этим требованиям. Передо мной предстает человек - худой, с пышной шевелюрой, с длинными артистическими руками и с прекрасной дикцией. И лишь потому, что это живое существо, которое смотрит на меня, говорит, причем с определенным диалектальным акцентом, дышит, как-то по-особенному закуривает сигарету, оно мне кажется куда более жизненным, чем порождение моей фантазии, поэтому я говорю себе: вместо того, чтобы создавать выдуманный типаж, я мог бы использовать этот. И я вижу, что результат может быть тот же, и даже более того: приведя в противоречие характер и тип, действие развитие сюжета может стать более эмоциональным. Затем появляется второй типаж, не очень худой, нечто среднее между первым и тем, что я выдумал, и мне кажется, что и этот актер может создать именно тот характер, который я задумал. Поэтому выбор персонажа становится для
} 
У Феллини есть целый ряд ярких повторяющихся образов, архетипических мотивов: Сарагина - огромная женщина, почти хтоническое существо - некий образ соблазнительно женского и одновременно праматери или праженского, мягкая любовница Карла, гермафродит, или более мифологический образ Минотавра и т. д. Порой режиссер акцентирует мир предметов. Так раковина, ее пластическое закручивание линий внутрь символически связаны с женским началом. Некоторые образы и темы кочуют из одного фильма в другой, создавая множество взаимоотсылок и сложных коннотаций, обозначая особую цельность творчества Ф. Феллини. Порой, кажется, что он снимает один и тот же фильм.

Творчество Феллини имеет прямое отношение к проблемам построения форм, к значению формообразования для человеческой культуры вообще и, в том числе, к принципам формального построения архетипа лиминальности в искусстве.

Почти магической космообразующей силой действия обладают образы-лица персонажей Феллини. И такой же магией воздействия обладает вещь в прикладном искусстве. Образная вещь - плоть-тело-идея обладает визуальной и тактильной притягательностью, которую можно было бы назвать переживанием (наслаждением) - визуальным, чувственным, тактильным и ментальным формы, следовательно - переживанием определенным образом организованной формы, и соответственно определенным образом организованного пространства, дающего душе и телу, то есть собственно человеческой сущности, те же эстетические переживания, что и формы, а также размышления интеллектуально-словесные «высокого» станкового искусства, и потому имеющие равный с ним смысл. Поскольку смысл любого искусства не в понятых словесных и интеллектуальных схемах, а в пережитых, познанных, прочувствованных человеком, человеческой сущностью формо-смыслах.

Важно, что при огромном богатстве лиц-формсмыслов-космосов Феллини его основной герой (Мастроянни) сам не имеет формы, как в переносном, так и в прямом смысле этого слова. Мир форм-космосов в его понимании, мироощущении, не имеет иерархии. Отсюда и специфика восприятия мира форм: толстые, худые, огромные, карлики, гермафродиты, чудовища, - все они равнозначны. Огромные женщины не воспринимаются как какой-то отвратительный вариант, а как образ-космос, могущий существовать вполне гармонично, свой мир и мир по-своему прекрасный. (В фильме «И корабль

меня поистине драматическим событием: все кандидаты подходят, все могут мне что-то дать, любой живой индивидуум меня волнует, в чем-то убеждает, дает толчок работе фантазии. Поэтому не раз случалось, что на самую маленькую роль я отбирал двадцать-тридцать кандидатов, которые потом могли проклинать меня всю жизнь,- ведь выбрать-то я должен был из них всех одного» [8, с. 184-185]. «Я считаю, что заставлять актера входить в роль - ошибка, и стараюсь никогда не совершать этой ошибки. Я всегда стремлюсь к обратному процессу, то есть пытаюсь сделать так, чтобы персонаж стал тем актером, которым я в данный момент располагаю» [8, с. 181-182]. плывет» герой остается в шлюпке вдвоем с носорогом - своеобразным чудо-юдо - и узнает тайну. У этого покрытого толстой кожей и панцирем чудовища, который кажется каким-то хтоническим, древним по происхождению существом, оказывается очень вкусное молоко, то есть очень земное, очень женское, поистине материнское начало.) Мир образов Феллини не похож на наш, где, к примеру, на 90 нормальных людей (то, что понимается под стандартом) приходится пять толстух, два карлика или два великана и т. д. Режиссер вдруг представляет мир толстяков или мир худосочных. Здесь нет строгой иерархии, они все выступают на равных, все эти формы-космосы-смыслы.

Феллини подчеркивает острохарактерность образов и форм лиц. Только главный герой не имеет четкого лицахарактера. Так Феллини, выбирая Мастроянни, говорил, что ему нужен человек с заурядным лицом. А кинокритики пишут о его особой отрешенной манере исполнения [9]. Феллини говорил: «Марчелло и я - это одно целое» [10], тем самым подтверждая выводы критиков о том, что герои Мастроянни - несомненное альтер эго автора фильмов.

Игра Мастроянни - это демонстрация и выражение полной растерянности, замешательства, непонимания где первое, а где второе, что можно и чего нельзя, что правильно, а что нет. Такая «растерянность» - это одно из наиболее важных состояний, достигаемых в процессе суфийских ритуалов, мистических странствий суфиев, нацеленных на духовное возвышение, получение духовного знания, «снятия завесы над тайной мироздания»... [11]; они обращены к скрытому от нас миру высокой духовности. Идеи и образы странствий, дорог, хаотичных приключений, блужданий, завесы-стены очень важны в творчестве Феллини.

Герой Мастроянни - это именно растерянный и плутающий среди других, ясных и конкретных образов персонаж, среди воспоминаний, фантазий, комплексов, мыслей и проблем. 0н «не имеет лица», а точнее - выражения лица: у него нет положительной или отрицательной реакции на то или другое; иными словами, он не имеет характера. Идет куда-то, куда его поведут, или сам бредет неизвестно куда. На что-то он мог бы негодовать, что-то бы его радовало, что-то оскорбляло в зависимости от его представлений. Но ему интересно всё, и всё он принимает на равных. Его игра - это поиск своего мира-смыслакосмоса, через поиск лица-образа. Через него он обретет мир, структуру, иерархию, порядок, космос и обретет свое собственное лицо, а следовательно, выражение лица. Его герой пребывает в некоторой нецеленаправленной ситуации. Получив структуру, он получит и цель. В этой модели состояния воплощена полнота возможностей. 0 н боится начать что-то, поскольку «каждый шаг вперед есть потеря», как писал Ю. Лотман [12]. Но это и есть состояние системы в точке бифуркации.

По существу в фильме «81/2» можно наблюдать поиск обретения лица-смысла-образа, персонажа для возможности дальнейшего творчества, то есть для создания про- 
изведения искусства, то есть некоей целостности, некоего космоса. Если режиссер Гвидо Ансельми найдет главного героя-героиню-лицо, то обретет и смысл всего произведения, в данном случае речь идет о создании фильма. «Нет роли и нет фильма», - говорит Гвидо.

И как эпиграф к фильму смотрятся первые кадры сон Гвидо, где он попадает в автомобильную пробку в тоннеле. Однако во сне ему (а это один из повторяющихся снов самого Ф. Феллини, как позднее становится известно из фильма «Интервью») удается вырваться из западни и воспарить в небо. Но в фильме события развиваются по-другому. Герой не может ни на что решиться. А кинокритик (один из персонажей) размышляет о похвале чистому листу, умении молчать, о том, что «ничто - вот подлинное совершенство». Гвидо спрашивает Клавдию, могла бы она бросить все, начать все сначала, выбрать только одно. Он говорит ей, что ищет персонаж, девушку, которая могла бы его возродить, она его спасение. Это задача героя, находящегося в точке бифуркации, кризисного состояния системы, момента неизвестности и выбора какого-то одного структурированного варианта. Роселла, подруга жены Гвидо, упоминает и духов, которые говорят главному герою, что он свободен, но должен научиться выбирать. Сцена купания в вине маленького Гвидо перекликается с фантастической сценой, где женщины несут его в простынях, он уподобляется ребенку (у В. Тернера - «утробному состоянию») или безвольному существу, лишенному всякой самостоятельности, существу, которое не может ходить. А уж само название фильма - это математически точный образ лименальности, пороговости, пограничности: ни 8 и ни 9, ни чет и ни нечет.

Та же проблематика характерна для фильма «Город женщин». Герой, все тот же Мастроянни, попадает в череду визуальных событий, бесцельно плывет в целом потоке женских образов, пытается встретить некую идеальную женщину (может, свою вторую половину?). Это и поиск других миров, некой константы. Женщины, с которыми он встречается, созданы его воображением, это «его проекции». Идеально женское оказывается полностью неуловимым, непознаваемым, непонятным, невозможным, а может и одним большим фейком. (Последние сцены фильма: герой в корзине воздушного шара, который представляет собой надувную куклу в виде сексуальнейшей невесты с нимбом из электрических лампочек, летит по небу. А героиня, прообраз невесты, расстреливает шар из автомата. Шар сдувается, превращая «прекрасные черты» в бесформенность.) $)^{3}$

\footnotetext{
${ }^{3}$ Похожий сюжет разыгрывается в «Казанова Федерико Феллини». На протяжении всего фильма идет поиск формы-образа-идеала, который выражается в поиске женщины. Тут, однако, зритель сталкивается с одним из немногих, казалось бы, острохарактерным главным героем в творчестве Феллини - Джакомо Казанова. Но его внешность искусственна, кукольна, сделана. Его образ - это его выдумка. Все лица и острохарактерны, и реальны, и только его лицо результат работы опытного мастера: сделанный благородный нос, нарисованные красивые четко очерченные губы, нарисованные высоко поднятые с изломом благородные брови. Постоянное «полное достоинства»
}

Найдет ли лиминальное, растерянное, ничего непонимающее и не имеющее собственного лица-характераформы-смысла-космоса существо - главный герой Феллини тот образ: форму-лицо-смысл, который наконец-то даст порядок этому хаотическому миру живых форм и характеров: тонкие, жутко толстые, бескровные, сексапильные, болезненно робкие, развратные, постоянно и равно с ними встречающиеся странные чудовища (что из них первично, что вторично?)? Устроится ли мир по некоторому порядку, смыслу, образу и подобию? Именно тогда он даст форму-ясность-четкость-структуру-смысл лицу и образу самого героя Феллини, самому Мастроянни, этому единственному необретшему смысл, единственному бесхарактерному, бесформенному, бессмысленному лицу в мире смысло-лиц.

Отсюда закономерный вопрос и вывод, важный для любого индивида. Найдет ли каждый человек образформу-смысл, ту или иную культурную парадигму, которая выстроит его душу, облик, мир, космос, сделает его человеком, принадлежащим и космическому, пространственному миру и миру социоисторическому, миру горнему и миру социальному? Если, конечно, он это не обрел с рождением, с молоком матери, с помощью ритуала ${ }^{4}$.

0бщий фон, на котором проходит действие «81/2», это жизнь отдыхающих на небольшом водном курорте. Режим санаторного лечения, процедуры, источник, грязи, душ - всё словно исключает героев из нормальной социальной и интеллектуальной жизни. Здесь нет места структурированным мыслям и структурированному обществу. Доминанта белого цвета, завес, простыней, белого пара, дыма, тумана, зонтиков, широкополых шляп, скрывающих лица, еще раз напоминает важные характеристики лиминальности: расструктурированность форм, беззнаковость и бесформенность.

Несколько по-другому рассматриваемые идеи звучат в «Джульетте и духах». В сюжете фильма размывается

выражение лица. Нижний костюм его весь на завязочках. Казанова словно связан ими, соединен из частей. Это марионетка, маска венецианского карнавала, с которого начинается фильм. Ему нет места в мире. 0н сам выдумал себе мир. Образ его мира кукла, которую он в конечном итоге находит.

${ }^{4}$ Интересно, что эта же идея нашла отражение в стихотворении Расула Гамзатова «Если б моя мама песен мне не пела...». Вот первые строки:

У меня бы не было языка родного, Собственного имени, голоса, лица, В странствиях далеких я давным-давно бы Заблудился, словно в космосе овца...

Я б не знал, как сильно, нежно, страстно, смело Ты, любовь, способна вспыхивать во мне, Если б моя мама песен мне не пела, Колыбель качая, как лодку на волне.

(Перевод Я. Козловского)

Именно концепция перехода (и его движущей силы) из лиминального состояния в мир природы и человеческой культуры объясняет столь парадоксальные слова этого стихотворения. С языком ясно - мать учит человека родному языку. Но почему без столь важной культурной парадигмы - песни матери у автора стихотворения не было бы «имени, голоса, лица» становится понятным только с точки зрения рассматриваемой концепции. 
грань между человеком и иным миром, миром духов, и открывается выход на проблемы лиминальности, к классической модели лиминальной ситуации.

Дух Олаф во время спиритуалистического сеанса говорит Джульетте: «Ты никто, никто. Ты ничего не значишь. Ты пустое место». По существу эта одна из главных характеристик лирического героя Феллини во всех его фильмах и одна из главных характеристик лиминальных существ у В. Тэрнера: «ни то и не се, ни там и не сям». В «Джульетте и духах» можно наблюдать целый ряд художественных структур, характеризующих лиминальность. Это использование образов детей-близнецов, широкие шляпы с пелеринами, под которыми как бы нивелируются формы, закрытые лица духов и монахинь. Хорошо известно о значении двоичности, расструктурированности форм, беззнаковости в проблематике лиминальности (белый цвет одежды в обрядах перехода, значение его символики для траура и свадьбы, условная бесформенность лиминальных существ). В фильме анализируется кризисная ситуация, момент душевных исканий героини. Это распад семьи, кризис любовных и сексуальных отношений. Мир Джульетты разомкнут. Она находится психически в пограничном состоянии: видит и слышит духов, ей представляются странные видения.

То, что происходит наяву, смешивается с фантазиями Джульетты. Все рассуждения ведутся вокруг понятия любви, тайны полов. Жрица любви Сюзи, гермафродит, духи - все пытаются постичь тайну любви и сказать об этом Джульетте. Ее семейное благополучие разрушается, муж изменяет ей, его отчуждение мучает ее. Реальное и ирреальное тесно переплетены и демонстрируют конфликт потаенных желаний, внутренних и социальных запретов и комплексов. Заложница своих страхов, она жаждет освобождения - и освобождает маленькую девочку - себя от огня (образ католической театральной постановки).

Интерес к подсознанию, мистике, снам, сеансам гипноза, медиумам, к тому, что происходит за контролируемой нашими мыслями чертой, прослеживается во многих фильмах Феллини. Его занимают пограничные состояния, психика, сумасшествие ${ }^{5}$.

Так «в своей последней картине “Голоса Луны" (1990) по повести Кевацонни режиссер представил мир с точки зрения безобидного помешанного, только что вышедшего из психбольницы» [10]. Главный герой, Сальвини, в исполнении Роберто Бениньи тоже слышит голоса, бродит по ночам. Он обращается к умершим и рассуждает о местечке, дыре, ведущей в другой мир. «Я не могу находиться в состоянии ожидания, будто на пороге. Вы должны мне помочь», - говорит он доктору.

Сцены вызова духов можно наблюдать не только в «Джульетте и духах», но и в «Сладкой жизни», и в «И ко-

\footnotetext{
${ }^{5}$ В 1968 году Феллини вместе с Луи Маллем и Роже Вадимом экранизируя три новеллы Эдгара По «Духи смерти», снимает фильм «Три шага в бреду», ставший ярким проявлением мистического в кинематографии с его характерным обращением к подсознанию.
}

рабль плывет». В «И корабль плывет» потусторонние силы вызываются и с помощью медиума, и в сербском танце, направленном на привлечение духов плодородия. Режиссер обращается к фольклорным формам, связанным с переходными обрядами (проводы зимы, сжигание чучела ведьмы в «Амаркорде», сербский танец).

Ну а цирк, клоуны, фокусники, столь любимые Феллини образы, продолжают нести рудименты шутовской культуры, ритуализированных архаических обрядовых персонажей, ряженых, где все замешано на проблемах маргинального, лиминального и мира иного. Традиция шутовства и органично связанные с ней балаган, карнавал, цирк и клоунада, их приверженность смеху занимают, несомненно, особое место в «культуре лиминального», деконструирующего нормативные позиции, клише и концепты. Тема цирка, веселых городских, площадных представлений особенно привлекала Феллини (это и «кочующие» из одного фильма в другой образы, и отдельные произведения: «Огни варьете», «Дорога», «Цирк»). Разрабатывая тему связи ряда образов Феллини и его эстетики с балаганным бутафорством и карнавалом, И.П. Уварова написала: «Но и Карнавал, но и Балаган вестники с того света, а их земное проявление сохраняет след хтонических глубин. <...> Все это можно найти в сокровищнице Феллини - там и карнавал, там и балаган с карликами-великанами, с патентованными уродами, да чего только нет там, в балагане Феллини» [13].

Можно сказать, что лиминальность как мироощущение определяет не только специфические характеристики творчества Феллини, но и его личные черты характера. Чувство юмора (одно время он даже работал карикатуристом), которое противостоит любому «клише, связанному со статусом и исполнением соответствующей роли», и позволяет увидеть многие явления и концепты с разных точек зрения. Прохладное отношение к спорту (то есть к некоторому простому целеполаганию). Или то, что он до последнего набирал своих героев, персонажей, затягивал время съемки фильма, пока продюсеры не начинали ругаться [7, с. 195].

Важно для раскрытия художественных основ «лиминальности» и то, что в работах Феллини ясно прослеживается тяга к кризисным моментам, моментам как бы распада общества, его структуры и иерархии, разрушения связей между людьми. В фильмах « $8 \frac{1}{2} 2 »$ и «Сладкая жизнь» $[14]^{6}$ нет не только иерархии форм. Здесь мы наблюдаем деконструкцию самих смыслов существования, а в «Сладкой жизни» еще и распад любого общественного поведения. В одном из первых эпизодов вертолет несет над Римом статую Христа7.

\footnotetext{
${ }^{6} 0$ близости образов и проблематики фильмов «81/2» и «Сладкая жизнь» не раз писала критика, проводя параллели между творческим и человеческим кризисом писателя-репортера Марчелло и режиссера Гвидо, поиском идеальной женщины Гвидо и образом Паолы, похожей на ангелов Пьетро Перуджино [14].

7 Примечательно, что рабочими названиями фильма были «2000 лет после Иисуса Христа» или «Вавилон 2000». См.: [15].
} 
Что это? Образ искусственности и забвения веры? Знак апокалипсиса, наступления времени хаоса, распада норм социального поведения, любого человеческого поведения, личного кризиса человека - писателя Марчелло и его друга, писателя Штайнера, и духовного кризиса общества, показанного сквозь призму жизни римской богемы и золотой молодежи?

Не случайно критики награждают «Сладкую жизнь» некоторым морализаторскими качествами. Действительно, с сильной натяжкой тему фильма можно уныло прочесть, как критику римской богемы. Прочтение, которое столь пугало Феллини. Режиссер говорил: «В мои намерения действительно не входило обличение нравов. Дискуссии об этом фильме, различная его интерпретация вызывают у меня чувство горечи и не из-за безосновательности, несерьезности и враждебности многих высказываний, а потому, что, возможно, они отвлекли зрителя от сути фильма <...> Меня действительно не интересовала возможность придать фильму полемическую направленность в том смысле, как вы ее понимаете. Я никогда не думал снимать фильм, проникнутый социальным духом и стремлением к политическому морализированию» [8, с. 188-191].

Его сюжеты, несомненно, выходят за рамки социального, они воплощают космические законы. Творчество Феллини - это особый уровень художественного прозрения и духовного опыта ${ }^{8}$.

В фильме «Сатирикон», где зрители наблюдают Римскую империю периода упадка и распада (картина снята по мотивам «Сатирикона» Петрония), два беспечных студента Энколпий и Аскилт встречают в своем бесцельном путешествии множество формо-смыслов, мужчин, женщин, гермафродита, чудовищ, монстров. Но эти два полных жизни и бесшабашного веселья «молодых животных», по выражению Феллини, не привержены никакому смыслу, никакой структуре. В конце фильма они встречают свое инициационное испытание, хотя и представленное в театрально-бутафорской форме, но реально опасное: они попадают в лабиринт и должны сразиться с Минотавром9.

\footnotetext{
${ }^{8}$ Рассуждая о фильме, Ф. Феллини писал: «Если действительно необходимо проводить эти параллели со столь знаменитыми людьми, я назвал бы имя Ювенала. То есть классического автора, у которого сквозь сатиру всегда проглядывает радостное лицо жизни; автора, подобного фокуснику, волшебнику, который любит жизнь, ибо жизнь, в общем, это не только то, что мы, живя, ощущаем при помощи наших чувств. Мне кажется само собой разумеющимся, что сквозь каждый предмет, каждое лицо, каждую фигуру, каждый пейзаж, как сквозь прозрачное стекло, видна их внутренняя сущность. Именно это я и пытался сказать, хотя мой фильм представляет собой панораму траура и руин. Эти руины освещает такой яркий, такой празднично-веселый, такой золотистый свет, что жизнь становится сладостно приятной, она все равно сладостна, пусть даже рушатся развалины и загромождают своими обломками твой путь. Ну, в общем, я хотел сказать, что этот фильм вовсе не ужасает, это неправда» [8, с. 179-180].

${ }^{9} 0$ связи лабиринта с инициационными обрядами, древними мистериями, магией, образами смерти и второго рождения, представлениями об инобытийном мире писали многие авторы. В том числе см.: [16, с. 3-15]. В психологии лабиринт символизирует сложную, запутанную ситуацию, из которой трудно найти выход.
}

Сюжеты фильма «И корабль плывет» разворачиваются на фоне трагических событий начала Первой мировой войны. («Мы сидим на краю жерла вулкана», - говорит эрцгерцог по поводу политической ситуации в своем интервью.) В замкнутом пространстве корабля сначала появляются мятежные сербы - знак хаоса политической нестабильности, а встреча с броненосцем австро-венгерского флота приводит к гибели корабля. Кораблю как образу в принципе присущи характеристики маргинальной и лиминальной ситуации ${ }^{10}$, как своеобразному ковчегу, лодке Харона, перевозящей души в царство смерти. На феллиниевском корабле собрались оперные певцы и певицы, чтобы отдать последнюю дань почтения оперной диве, Эдмэи, развеять ее прах над островом в море, где она родилась (своеобразные похороны - классический случай обрядов перехода). Здесь к характеристикам героев лиц-форм-смыслов-образов добавляются еще их оперные голоса. Стройный хор голосов словно противостоит распаду в последних сценах гибели корабля.

В фильме, по существу, нет ясного сюжета и фабулы. Повествование ведется от лица журналиста, который представляет зрителям пассажиров корабля и все происходящее. Этот принцип нелинейного, нецеленаправленного сюжета, калейдоскопа интервью прослеживается и в фильмах «Интервью» и в «Джинджер и Фред». 0браз репортера-рассказчика появляется в «Амаркорде», в «Голосе луны», в «Репетиции оркестра». Нецеленаправленный, хаотический сюжет, состоящий из отдельных тем, характерен для многих фильмов Феллини. Вот, например что говорил Феллини о процессе создания и композиции фильма «Сладкая жизнь»: «Когда я с моими помощниками предпринял попытку создать историю, которая обобщала бы и показывала противоречия, неуверенность, усталость, абсурдность, неестественность определенного образа жизни, то, словно слыша потусторонний голос, стал повторять себе: нет, не надо заботиться о создании повествования, этот фильм не должен представлять собой сюжетную историю. Поступим лучше так: сложим вместе весь собранный материал, поговорим откровенно, поделимся мыслями, вспомним о том, что мы читали в газетах, в комиксах. Положим все наши заметки, все документы на стол в самом хаотическом виде.

Потому что (пусть вам это покажется довольно странным способом теоретизировать), если мы хотим сделать фильм, который должен явиться свидетельством хаоса переживаемой ныне эпохи, то и форма его должна быть возможно более хаотичной» [8, с. 188-189].

Но еще больше, чем «хаосу переживаемой ныне эпохи», данный композиционный принцип соответствует принципам энтропии и лиминального хаоса, внутренней сути художественных образов Феллини.

Яркими персонажами, олицетворяющими хаос в «Сладкой жизни», представляются папарацци, всюду снующие группы и банды фоторепортеров. Это не просто

\footnotetext{
${ }^{10} 06$ этом см.: [17, с. $\left.174-191\right]$.
} 
образ «копошащегося человеческого муравейника» [8, с. 192], показать который стремился режиссер. Это те, кто выхватывают из самой логики жизни, вырывают из контекста яркие события, утрачивающие с их помощью какой-либо смысл и превращающиеся в информационные сенсации. Они не освещают явления, а уничтожают понимание, разрушая сами основы мировосприятия.

Еще одна тема, которая волнует Ф. Феллини, - это собственные детские воспоминания, мир и переживания ребенка. К примеру, подростка Титто в фильме «Амаркорд». Ребенок-подросток воспринимает мир свободно, без структуры и только с возрастом должен обрести социальный статус, структуру (характерное положение неофита). Этому миру противостоят возможные системы организации, порядка, существования, активности, целенаправленности жизни. И снова режиссер создает здесь богатство форм, лиц и образов, окружающих мальчика и обнаруживающих сюжет поиска выхода из неофитской ситуации отсутствия иерархий космосов-образов-форм.

«Амаркорд» также начинается с похорон - похорон зимы. На улице на огромном костре сжигают чучело ведьмы. В «Амаркорде» анализируется юношеско-детское деструктурированное восприятие, охватывающее формальное богатство мира, и фашизм как вариант полной структуры, имеющей только одну направленность. Основной эталон - мужские лица и типы в фашистских мундирах. Большинство жителей маленького городка члены фашистской партии. Это не значит, что только эта иерархически жесткая система согласуется с рассматриваемой общественной ситуацией. Хотя и существует как бы всеобщее социальное участие в фашистском мироустройстве. Все подчинены этому, имеют свои места (показаны детские и юношеские фашистские организации). Но для подростка Титто это только вариант лиц и образов, которые захватывают и включают в себя часть корреспондирующих им других миров. Однако Сарагина, сексапильная дамочка Градиска, продавщица в табачном магазине, первые сексуальные фантазии, сумасшедший дядя Тео, «король океана» - огромный великолепный корабль «Рекс» или вдруг появившийся графский павлин имеют гораздо большее значение для мальчика.

В фильме обыгрываются образы детства, отца, матери, воспоминания. Мать - это тот первый образ, который дает будущему взрослому человеку хоть какую-то структуру, ориентацию, форму, сообщает ему основные устои, некое начало начал. В «Амаркорде» рассуждения дедушки Титто о густом тумане, вдруг окутавшем маленький городок, раскрывают лиминальный характер целого ряда любимых Феллини формальных художественных приемов. А именно его любовь к туману, дыму, пару, дымовым шашкам, которая прослеживается во многих фильмах. «Туман, - говорит дедушка, - все вдруг исчезло: люди, деревья, вино. Если это и есть смерть - то это не здорово».

Фильм «Репетиция оркестра» - это почти притча: рассуждение о структуре и деструктурализациии, яркая метафора проблемы «коммунитас-структура». Дирижер олицетворяет собой власть, волю, энергию (в конце, кстати, сбивается с итальянского на отрывистую немецкую речь командного тона), образующих из хаоса характеров (музыкант - музыкальный инструмент - звук) космос: оркестровую музыку, оркестр, играющий музыку.

В фильме «Интервью» демонстрируются различные возможности мироорганизаций на киностудии. На «Чине Чита» можно прожить несколько вариантов жизни, встретить и создать множество образов. Почему одно предпочесть другому? Опять нет точного сюжета и фабулы, прослеживается тип интервью, своеобразного парада, калейдоскопа тем. В этот хаос обрывков сюжетов, сценариев различных фильмов и образов попадает один из героев - юный журналист Серджо. Ему Феллини просит сделать прыщик на носу, чтобы он чувствовал себя растерянным и подавленным перед красивой, известной актрисой, у которой он должен взять интервью. Перед нами тот же растерянный герой. Компания Феллини (они собираются снимать «Америку» по Кафке) опять подбирает персонажи, типы, пытаясь разгадать, что они значат. (В «Сладкой жизни» в сцене с Анитой Экберг Мастроянни уже задавал вопрос: «Кто ты? Мать, море, Ева, первая женщина на земле?») Однажды Феллини спросили: «Как Вы управляете этим хаосом?» Он ответил: «Я им не управляю, я его создаю».

В начальных сценах вновь звучит тема сна. Сон, фантазия и воображение очень значимы для творчества Феллини. Сон - это все то же пороговое состояние, когда открывается путь к подсознанию. Феллини упоминает о сне, где он в темноте упирается в стену и ощупывает ее (сходно с темой «Завесы»). Обычно он находил в себе силы, воспарял вверх и вырывался из этой ситуации. Здесь явно моделируется ситуация, аналогичная снуэпиграфу в фильме «81/2».

Вопрос о духовном значении выбора того или иного пути-структуры-формы, его одновременно ограниченности и возможной полноте звучит в фильме «Джинджер и Фред». Престарелые герои Марчелло Мастроянни и Джульетты Мазины - одни из многих, кто должен выступить в своем сценическом или жизненном амплуа перед зрителями на ретроконцерте. Перед нами целый калейдоскоп, парад образов - жизненных сценариев. Искусство этих персонажей вторично, они копируют знаменитую американскую пару 1930-х годов, танцовщиков Фреда Астер и Джинджер Роджерс и принадлежат к армии их эпигонов. Они не открыли и не создали ничего своего в искусстве. Там за сценой у них есть семья, дети - жизнь, которая кажется более полной. Но Джинджер говорит Фреду, что когда она с ним танцевала, а вернее в один момент, когда она ждет его на берегу в легком голубом платье и машет ему, а корабль подплывает, она испытывала такое счастье, которое не испытала в своей жизни. Истинное, абсолютно полное чувство главных героев оказывается пережитым в этой небольшой роли, сыгранной в молодости, в их так и не случившейся любви. Иными словами, в 
своем ограниченном сценарии человек может пережить и переживает всю полноту мирочувствования, целостность бытия, воплощенную, в данном случае в улыбке, и ощущение полного счастья Джинджер. Потому-то это счастье и улыбка счастья имеют глобальный смысл, выражая тот абсолютный эмоциональный объем, что заключен в сердце человека. Это дар. Не зря Ф. Феллини писал: «Я полагаю, что “естественным образом" религиозен, ибо весь мир, вся жизнь мне кажутся сокрытыми тайной» ${ }^{11}$. Эта религиозность далека от простой веры в чудеса, но связана с ощущением таинственности человеческого бытия.

Данная тема обыгрывается в фильме «Ночи Кабирии»: простые, порой экзальтированные и даже загнанные в рамки церковного бюрократизма, но не лишенные искренности формы массовой католической народной религиозности и обрядовости ${ }^{12}$ и поразительная, простая и ясная, бесхитростная улыбка Кабирии в конце фильма. Это искра Божья, ее отклик на счастливые молодые лица улыбающихся ей ребят, счастливых без видимой причины. «Тот, кто находится в милости Божьей, тот испытывает удовлетворение» - это слова-наставления францисканского монаха, брата Джованни, звучащие в фильме, свидетельствуют о религиозном значении чувства радости, счастья, любви. И здесь снова стоит вернуться к проблеме Гвидо Ансельми, к причине невозможности его творческого и жизненного выбора, которую формулирует Феллини в фильме «81/2»: Это происходит, «потому что [Ансельми. - П.Г.] не верит в новую жизнь» или «потому что не умеет любить» [14]. Таким образом, в творческой фантазии Ф. Феллини не только реализуются сложные и таинственные архетипы сознания, такие как лиминальность и связанные с ней теории энтропии и точки бифуркации, характерные для широкого круга систем, но и утверждается особая ценность энергии человеческого и человечности.

В результате анализа нескольких работ Феллини становится ясно, что такое понятие как лиминальность может быть творческой матрицей, архетипом, охватывающим как структуру произведения, так и его образный строй, характер героев. Этот архетип - одна из основ мироощущения, сознания и личности самого Федерико Феллини. Юнг писал: «Тот, кто говорит архетипами, глаголит как бы тысячей голосов $<\ldots . .>$ он подымает изображаемое им из мира единократного и проходящего в сферу вечного, притом и свою личную судьбу он возвышает до всечеловеческой судьбы» [1].

Духовно богатая и насыщенная «зона лиминальности» реализуется в творчестве Феллини с необыкновенной полнотой, последовательностью, точностью, в многообразии ее проявлений. Это и момент духовного насыщения, и точка неустойчивого состояния человеческой души и социума. Анализ данной структуры вряд ли делает скрытый от человека мир духовного более понятным, так же как и принципы его освоения посредством сознания.

\footnotetext{
${ }^{11}$ Цит. по: [18, с. 449].

12 Похожая тема - явление Мадонны детям в «Сладкой жизни».
}

Оторваны ли «матрицы сознания», человеческие фантазии от реальности или являются механизмами и способами ее познания в тех истинных формах, в которых она существует? Ученые исследуют многие явления культуры и сознания, для которых они выработали те или иные понятия, такие как архетип или быличка (как жанр фольклора и концепт литературоведения), или вуайерист. Кажется, что с их помощью мы раскрыли и поняли суть самого явления, поймали его в силки разумного. Однако суть их и специфика остаются непонятыми и иррациональными.

«Я питаю, - писал великий художник, - глубокую веру в фантазию - она является не чем-то, свойственным психически больным, а присутствует в самой жизни. Я верю в фантазию, которая принадлежит жизни и обладает объемом и масштабами куда более реальными, чем то, что мы считаем физическим измерением» [8, с. 180].

\section{Список литературы}

1. Аверенцев С. Архетип Мифы народов мира [Электронный ресурс]. - Режим доступа: http://www.psyoffice.ru/5enc_myphology-1657.htm

2. Тернер В. Символ и ритуал. - М., 1983.

3. Богемский Г. В поисках человека // Федерико Феллини. М.: Искусство, 1968.

4. Виктор Тернер [Электронный ресурс] // Википедия. - Режим доступа: http://ru.wikipedia.org/wiki/

5. Выгодский Л.С. Психология искусства. - М.: Искусство, 1986.

6. Александр Тышлер (1898-1980). Живопись, графика, скульптура, театр: каталог выставки к 85-летию со дня рождения / сост. Ф.Я. Сыркина; автор вступ. ст. Д.В. Сарабьянов. - М.: Советский художник, 1983.

7. Чедерна К. Полная путаница // Феллини о Феллини. - М.: Радуга, 1988.

8. Федерико Феллини. - М.: Искусство, 1968.

9. Марчелло Мастроянни [Электронный ресурс] // Википедия. - Режим доступа: http://ru.wikipedia.org/wiki/

10. Федерико Феллини [Электронный ресурс] // Википедия. Режим доступа: http://ru.wikipedia.org/wiki/

11. Сама [Электронный ресурс] // Википедия. - Режим доступа: http://ru.wikipedia.org/wiki/

12. Лотман Ю.М. о природе искусства [Электронный ресурс]. - Режим доступа: http://vivovoco.rsl.ru/

13. Уварова И.П. Диковинный зверинец или «Сага о носороге» [Электронный ресурс]. - Режим доступа: http://rmvoz.ru/ forums/index.php?topic $=2930.0$

14. «81/2» [Электронный ресурс] // Википедия. - Режим доступа: http://ru.wikipedia.org/wiki/

15. Майзель Е. Жизнь после оргии (о фильме «Сладкая жизнь») [Электронный ресурс]. - Режим доступа: http://www. cinematheque.ru/post/142662

16. Гамзатова П.Р. Инобытийное пространство в традиционной культуре и художественных системах (универсальная модель, когнитивные аспекты) // Традиционная культура. 2007. — № 1.

17. Давыдов А.Н., Теребихин Н.М. Порт и корабль: семантика северорусской морской культуры // Механизмы культуры. - М., 1990.

18. Громов Е.С. Структура волшебства // Феллини о Феллини. М.: Радуга, 1988. 